\title{
The Analysis of Performance Management System in a Local Basically on Armstrong's Approach and Baron Models
}

\author{
Lilis Sri Sulistiani \\ Doctoral Programme of Public Administration, Faculty of Social and Political Science, Universitas Diponegoro, Semarang - Indonesia
}

\begin{abstract}
This study aims to analyze the performance management system implemented on local government, using performance management model by Armstrong and Baron. In this study the model used as the basis to identify the aspects of performance management have been applied or are not yet available. Research is done in the Banyumas District Government uses qualitative research methods, methods of data collection through interviews in depth and interactive methods of analysis. The focus of research is performance management system with the following aspects: Organization Mission and objectives of the strategic and business plan, objectives of the Department, the deal's performance and development, performance and development plans, development work and action monitoring as well as feedback, formal review and feedback, and the comprehensive performance assessment. The results showed that the planning performance already compiled in the integrated work planning proposal which is a result of the networking of the various sub organizational units. The planning of this work was used as the basis for drawing up an agreement of work organization and employees. Implementing performance assessment already exists at any level in accordance with the agreement of performance, namely the assessment of program realization, the performance of the Organization and employees. Monitoring and feedback is organized according to the type of assessment i.e. work programs, organizations and individuals. The results of the performance assessment product has not been made into the basis for the granting of rewards that can motivate employees and the aspect of employee development plan has not been carried out properly.
\end{abstract}

Keywords: Performance Management System; Performance Assessment; Local Government.

\section{Introduction}

The success of the organization in achieving the objectives that have been set depending on the resources quality which are owned, such as natural resources, human resources, environment, financial, institutional and equipment. A country that has abundance of resources especially unrenewable resources will face a boomerang situation. Hence, country or an organization needs the capability of technology and human resources.

One of the most important of the various resources is human resources because it is a valuable asset owned by the Organization [1]. Therefore, each organization should have the ability to manage resources, either human resources or other resources. One of the important things that must be done to get the best performance from those human resources is through performance management. Where performance management can be described as a policy, strategy and techniques intended to direct the attention of the Manager and the employee towards the improvement of organizational performance [2].

Performance management is the process of designing and implementing strategies, motivation, intervenes and directs the aim to transform the raw potential of human resources in performance [3]. Performance management is the process of identifying, measuring, managing, and developing the performance of human resources within an organization. Management performance is a systematic analysis and performance measurement of the workers that implemented to improve the performance over time [4].

Performance management has benefits that can be felt by the employees and the Organization [5], and is an important system to get information about the employee performance [6].

*Corresponding author: lilissfz@gmail.com 
Implementation of performance management in the environment of Local Government still encountered various obstacles, such as:

a. This process is not started from a clear planning [7]

b. Management performance is considered as annual events or routine and not an ongoing process [8]

c. Instruments, mechanisms and processes that are done haven't been able to measure the contribution of each Civil Servants against the achievement of the organization objectives [9]

d. Performance management has not been supported by accurate performance assessment [10]

Based on the background of those problems above then the problem in this research is: How does performance management model-based Armstrong and Baron implemented in Banyumas Regency Government?

The history of the emergence of the earliest performance management found at the time of the Wei Dynasty Emperor (AD 221-265) in China that have the Evaluator in charge of Empire to evaluate the performance of the family officially. Centuries later, Ignatius Loyola (1491-1556) established a formal rating system for community member of Jesus (Jesuits) [11].

Performance management appears first as a formal monitoring system, however, evolved from the work of Frederick Taylor and his followers before World War I. The assessment for officers in the U.S. armed forces who was introduced in 1920, and this spread to the United Kingdom in the 1950 's and 1960 's, when it is sometimes named as the performance assessment. Then it is known by management based on targets that appear simultaneously in 1960's and 1970's. Furthermore, after a critical incident technique experiment and scale-based assessment of behavior, as the revision of the model result oriented appeared universally in 1970's and is still used to this day. The term performance management was first used in 1970's, but has not yet become a recognized process until the mid-1980's.

Performance management can be defined as the activity of managing employee performance in order to achieve the Organization objectives [12] . which is emphasized in the performance review or assessment, may also be interpreted as a Manager and communications officers that focus on understanding the work [13]. Whereas Sahu suggested a system of performance management is a process planning performance (goal setting), performance monitoring and coaching, measuring individual performance (evaluating) related to the objectives of the Organization, giving responses, individual awards based on their progress toward the goals of performance and competence required, and working out a plan for the development for itself [14].
The term performance management and performance appraisal are sometimes used interchangeably [6]. Even often considered as a synonym but the two terms are indeed different. Performance management is a comprehensive, sustainable and a loose approach towards the organizations management, teams and individuals involving the maximum number of dialogue between their attentions [3]. While the performance assessment is a more limited approach, which involves a manager makes a top-down assessment [6].

In giving a more systematic performance management system, then according to Armstrong is done through a modeling provides a useful means of summing up how performance management can work communicated to employees and provide the basis for education and training activities [6].

There are several models of performance management that can be used as a reference in implementing performance management. The model is as follows: (a) Deming Model; (b) Model Torrington and Hall; (c) Costello d Models; and (d) Armstrong and Baron Models. Armstrong and Baron models consists of several stages, as follows: mission organization and objectives, business and department plans and objectives, performance agreement, performance and development plan, work action, monitoring and feedback, review formal and feedback, measuring performance, and reward.

\section{Methodology}

The approach used in this study is a qualitative approach. This approach is used to analyze system performance management in Banyumas Regency Government. The technique of data collection conducted in-depth interviews with (in-depth interviews), direct observation, and documentation. Data analysis uses is interactive model [15].

\section{Discussion}

The first order of performance management model is the Organization's mission and strategic objectives of the organization which is the starting point of the performance management process. These activities are conducted jointly between the employees and the leadership to discuss the expectations of their performance [16]. The preparation of a plan of work done in Banyumas Regency Government was done in accordance with the guidelines and rules set forth by the Government.

This activity starts with the preparation of RPJMD (Medium-Term Development Plan Area) which is a regional development planning documents for 5 years period which contains a definition of vision, mission and program head region with guided RPJP (Long Term Development Plan) Region as well as paying attention to 
the RPJM (Medium-Term Development Plan) (article 1 of ACT Number 4 Number 17 in 2007 on "The LongTerm National Development Plan in 2005-2025 Period).

The next process is a very important agreement was the contract performance or the agreement performance which is reached among individuals with a direct supervisor about the target and its accountability. The preparation work done deal earlier in the year by each individual based on the Organization's work plan and basic tasks. Performance agreement documents used as a basis to compare between the target that has been set with the realization of product performance, guidelines for career development, the basic determination of training needs, standard payroll, employee and mutations.

The next step is to implement a plan that's been mutually agreed between leadership and employees. In this process performance management helps the individual to be ready to act so as to achieve results as planned. Performance management ensures that the activities of every employee in the job exercise always leads to the objectives achievement of the organization. Where necessary will be conducted training for human resources development.

The next process is to conduct a formal review. Monitoring and evaluation is performed in accordance with the work program both of Organization and Individual. Work program will be evaluated on a regular basis every quarter by Bappeda. Each organization is obliged to report the local government development program realization. While monitoring the performance of the individual will be held every end of the month. In this process each unit of the Organization delivering the product performance and various obstacles faced in realizing the plan. Obstacles faced at this step are that the required data for compiling the evaluation is often incomplete. This is caused because there are few holders of official activities do not submit the report on time has been set.

Assessment of performance against the officers was conducted at the end of the year, by comparing the targets set with the realization of product performance. Performance assessment is given at this point really depends on the perception and understanding of the immediate supervisor so that more subjective in nature. This happens because the existence of performance assessment standards that can be used objectively. The results of the assessment of the performance of municipal employees district close to Banyumas as much as 3 persons with the category of excellent, 11.716 persons category of good, and 1 person category is enough.

The next process after performance appraisal is rewards. In addition to the salary received periodically, employees get incentives in the form of money called additional employee income (tamsilpeg). The amount of incentive is given in accordance with the specified assessment and is not related to the performance appraisal result.

\section{Conclusion}

Performance-based management approach OF Armstrong and Baron generally has been conducted properly, especially at the step of planning and drafting performance agreements the performance. However, there are several steps still have constraints, i.e. on performance assessment and granting activities in return for product performance. Performance assessment is still done as a routine, where the results of performance assessment in both the level of the individual or organization has not legal basis for granting rewards.

\section{References}

1. M. D. Tovey and M. L. Uren, Managing Performance Improvement, Pearson, Australia (2010).

2. A. Rhys and T. Entwistle, Public Service Efficiency, Routledge, London (2010).

3. S. R. Kandula, Performance Management: Strategies, Interventions, Drivers, Delhi, Sage Publication (2014).

4. R. N. Lussier and J. R. Hendon, Fundamentals of Human Resource Management: Function, Application, Skill Development, California, Sage Publishing (2017).

5. K. Frayer and J. Anthoni, Performance Management in the Public Sector, Int. J. P. S. M. 2009, Vol 22, Issue 6 pp 478-498 (2009).

6. M. Armstrong, Handbook of Performance Management: An Evidence-based Guide to Delivering High Performance $4^{\text {th }}$ edition, London, Kogan Page (2009).

7. C. Anwarruddin, The Distribution and Status of Hoolock Gibbon, Hoolock Loolock, in Manipurn Meghalaya, Mizoram and Nagaland in Northeast India, Primate Conservation vol:269 (2006).

8. A. Rodney, S. Hazllet, and C.Cassey, Performance Management in the UK Public Sector, Int. J. P. M. S. 2005, Volume 18:3 pp 256 (2005).

9. J. Wahyudi, Penilaian Kinerja Pegawai Negeri Sipil (Kajian Pra Implementasi Peraturan Pemerintah Nomor 46 Tahun 2011 Tentang Penilaian Prestasi kerja PNS di Lingkungan Pemerintah Kabupaten Barito Timur, J. A. P. B., Volume 1 No. 3, 2014, artikel 3 (2014).

10. J. Ock and F. Oswald, Managing the Interpersonal Aspect of Performance Management, Industrial and Organizational Psychology, Volume 8, Issue 01, pp. 111-119 (2015). 
11. B. D. Singh, Performance Management System: a holistic approach, New Delhi, Excel Books (2010).

12. Elearn, Development For High Performance, Routledge (2009).

13. Calvert, The Future of Performances, Library Review (2004).
14. Sahu, Measuring Service Quality in an Academic Library: an Indian Case Study, Library Review (2007).

15. M. B. Miles and A. M. Huberman, Qualitative Data Analysis: a Sourcebook of New Methods, California, Sage Publishing (2014).

16. E. D. Pulakos, Performance Management: A New Approach for Driving Business Results, WileyBlackwell (2009).

$\overline{{ }^{*} \text { Corresponding author: lilissfz@gmail.com }}$ 